\title{
Influence of Essential Oil Fractionation by Vacuum Distillation on Acaricidal Activity Against the Cattle Tick
}

\author{
Fernando Cidade Torres ${ }^{1,2}$, Aline Machado Lucas ${ }^{1}$, Vera Lucia Sardá Ribeiro², João \\ Ricardo Martins ${ }^{3}$, Gilsane von Poser $^{4}$, Maria Silvia Guala ${ }^{5}$, Heriberto Victor Elder ${ }^{5}$ and \\ Eduardo Cassel ${ }^{*}$ \\ ${ }^{1}$ Laboratório de Operações Unitárias; Faculdade de Engenharia; Pontifícia Universidade Católica do Rio Grande \\ do Sul; Av. Ipiranga, 6681; 90619-900; Porto Alegre - RS - Brasil. ${ }^{2}$ Laboratório de Acarologia e Entomologia; \\ Faculdade de Veterinária; Universidade Federal do Rio Grande do Sul, Av. Bento Gonçalves, 9090; 91540-000; \\ Porto Alegre - RS - Brasil. ${ }^{3}$ Instituto de Pesquisas Veterinárias Desidério Finamor; Estrada do Conde s/n; Guaíba - \\ RS-- Brasil. ${ }^{4}$ Programa de Pós-Graduação em Ciências Farmacêuticas; Universidade Federal do Rio Grande do \\ Sul, Av. Ipiranga, 2752; 90610-000; Porto Alegre - RS - Brasil. ${ }^{5}$ Facultad de Ingeniería Química; Universidad \\ Nacional del Litoral; Santa Fe - Argentine
}

\begin{abstract}
The aim of this work was to study the influence of essential oil fractionation on acaricidal activity against the cattle tick Rhipicephalus (Boophilus) microplus. The citronella (Cymbopogon winterianus J.) and pepper tree (Schinus molle L.) essential oils were fractionated by vacuum distillation yielding fractions that were analyzed by the GC/MS. Laboratory tests were carried out to determine the effect of the total essential oil and fractions on larvae of the cattle tick R. (B.) microplus. The fractions 04 and 05 of the $\mathrm{C}$. winterianus essential oil were the most active showing $L C_{50}$ values of 1.20 and $1.34 \mu \mathrm{L} / \mathrm{mL}$, respectively. The $L C_{50}$ of the total oil was $3.30 \mu \mathrm{L} / \mathrm{mL}$ while the effect of the fractions 01, 02 and 03 was less pronounced, with $L C_{50}$ values of 4.37, 4.24 and 3.49 $\mu \mathrm{L} / \mathrm{mL}$, respectively. The fraction 03 of the $\mathrm{S}$. molle essential oil was the most active showing $L_{50}$ value of $8.80 \mu \mathrm{L} / \mathrm{mL}$ while the fractions 01 and 02 did not show toxic effects on the larvae.
\end{abstract}

Key words: Cymbopogon winterianus J., Schinus molle L., acaricidal activity, vacuum distillation, Rhipicephalus (Boophilus) microplus

\section{INTRODUCTION}

The cattle tick Rhipicephalus (Boophilus) microplus represents a major problem for the cattle production in several regions of the world. It causes blood loss, reduction in both weight gain and milk production. It also serves as a vector for certain diseases such as bovine babesiosis, a cattle tick-borne disease caused by the haemoprotozoan parasites of the genus Babesia, and anaplasmosis, caused by obligate intracellular bacteria of the genus Anaplasma that parasitize erythrocytes and monocytes of higher vertebrates, mostly ruminants. In addition, the parasite causes damage to skin of the cattle directly affecting the value of hides for leather manufacture (García-García et al. 1999; Ducornez et al. 2005). The economical losses world-over were estimated as $\$ 7$ billion (Castro-Janer et al. 2009) due to this.

The most extensively used methods for tick control involve the application of acaricides such as pyrethroids and formamidine, both in the

*Author for correspondence: cassel@pucrs.br 
environment and directly on the animal skin. However, the indiscriminate use of these substances leads to increase in acaricide resistance and environmental contamination (Chagas et al. 2002; Chagas 2004). Therefore, effective and easily accepted methods of tick control are extremely necessary (Cordovés 1997).

Natural products can be considered a valuable alternative. A large number of plants and entomopathogenic agents have been reported to have acaricidal effect against the diverse stages of several species of ticks such as Ixodes scapularis and $R$. (B.) microplus (Borges et al. 2003; FreitasRibeiro et al. 2005; Dietrich et al. 2006; Ribeiro et al. 2007; Fernandes et al. 2008; Ribeiro et al. 2008). Among them, essential oils components are known to possess repellent, chemosterilant, antifeeding and biocidal activities against different acarus, showing promissory potential as products for tick control, since some of them are selective and have little or no harmful effects on non-target organisms (Facey et al. 2005; Panella et al. 2005; Dietrich et al. 2006; Tunon et al. 2006; Apel et al. 2009).

The genus Cymbopogon, family Poaceae, comprises a group of about 40 tropical aromatic grasses. The essential oils from several species of this genus have demonstrated insecticidal and repellent activity (Kim et al. 2004; Ketoh et al. 2006; Samarasekera et al. 2006). The citronella (Cymbopogon winterianus $\mathrm{J}$.) essential oil presents repellent properties and represents a significant parcel of the essential oil national production being used in sprays, soaps, candles and other mosquito repellent products (Tanu and Adholeya 2004). Studies performed with the oil distilled from the leaves of citronella showed high acaricidal activity against the larvae and adult females of the cattle ticks when pure oil and diluted (1:4) in ethanol (Chungsamarnyart and Jiwajinda 1992) was used. Olivo et al. (2008) investigated the effect of the essential oil of citronella on $R$. (B.) microplus engorged females and reported $90 \%$ of egg laying inhibition at the concentrations of $1,10,25$ and $100 \%$. Other study carried out with $C$. winterianus essential oil demonstrated that the concentrations of 6.1 and $4.1 \%$ were lethal to engorged females and larvae of $R$. (B.) microplus, respectively. Hatching was not observed in the eggs from the engorged females treated with the essential oils at the concentration of $7.14 \%$ and egg lying was inhibited by the oil at $10 \%$. Citronellal, geraniol and citronellol were the main components identified in the essential oil (Martins 2006).

Schinus molle L. (Anacardiaceae) is a tree from the South America, originating from Peru (Huerta et al., 2010). It has active substances, such as terpenes, tannins, alkaloids, flavonoids, essential oils, and oleoresins, mainly in the leaves and fruits (Ferrero et al. 2007). Ferrero et al. (2006 2007) studied the insecticidal and repellent effects of the extracts from S. molle. Hayouni et al. (2008). Investigated the antimicrobial activity of pepper tree essential oil.

In this work, the essential oils of $C$. winterianus and $S$. molle were fractionated by vacuum distillation (Babu and Kaul 2007) and tested against $R$. (B.) microplus.

\section{MATERIAL AND METHODS}

Plant material and extraction of the essential oil The aerial parts of $C$. winterianus were collected from the Experimental Farm of Tekton Óleos Essenciais Ltda in the state of Rio Grande do Sul. The essential oil was extracted from the fresh aerial parts by steam distillation in the Tekton industrial distillery (Cassel and Vargas 2006; Cassel et al. 2009). The average yield of the extraction, $0.62 \% \mathrm{p} / \mathrm{p}$, was calculated on a wet weight basis from the relationship between the essential oil mass and mass of leaves of the fresh aromatic plants.

The $S$. molle essential oil was extracted from the fresh plant (fruit $-25 \% \mathrm{p} / \mathrm{p}$; leaves $-65 \% \mathrm{p} / \mathrm{p}$; stems - $10 \% \mathrm{p} / \mathrm{p})$ by steam distillation. The average yield of the pepper tree essential oil on industrial scale was $0.30 \% \mathrm{p} / \mathrm{p}$. The fresh plants were collected and the essential oil was extracted in Experimental Center Angel Gallardo.

\section{Essential oil fractionation}

The essential oil was fractionated using a vacuum distillation apparatus (Fig. 1). A volume of $300 \mathrm{~mL}$ was introduced in a round bottom flask that presented three outputs: output B had a capillary tube aiming to control and stabilize the ebullition inside the round bottom flask; the output TC1 was used to introduce a temperature sensor for the control of essential oil temperature during the distillation in order to avoid very high temperatures, and the third output was employed to connect the packed column. 
The fractionating column was $1.5 \mathrm{~m}$ in height and was packed with titanium alloy. The packing material was selected in order to protect against the corrosion. The measure of temperature at the top of the fractionating column was determined by the thermocouple with a precision of $\pm 1.5{ }^{\circ} \mathrm{C}$.
Temperatures in the condensers were controlled by a thermostatic bath (TECNAL, Model TE-2000) and the maintenance of the system pressure was made by vacuum pump (TECNAL, Model TE058).

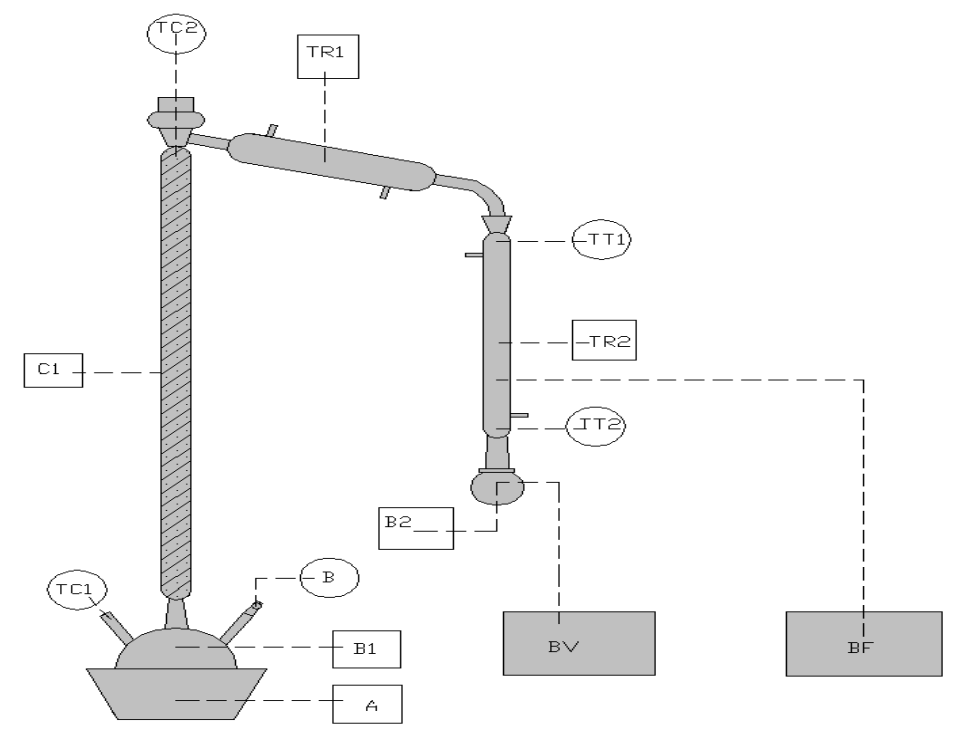

Figure 1- Schematic diagram of the vacuum distillation apparatus: B1 - round bottom flask; $\mathrm{C} 1$ packed column; TR1 and TR2 - condenser, B2 - sample flask, BV - vacuum pump; BF - thermostatic bath, TC1, TC2 - temperature controllers.

\section{Qualitative and quantitative analyses}

The quantitative and qualitative analyses of the oils were performed by the capillary GC/MS on an Agilent_7890A mass selective (MS) detector system operating at $70 \mathrm{eV}$ using a $\mathrm{HP}-5 \mathrm{MS}$ capillary column $(30 \mathrm{~m} \times 0.25 \mathrm{~mm} \times 0.25 \mu \mathrm{m})$. Injector and detector temperatures were set at 60 and $325 / 350{ }^{\circ} \mathrm{C}$, respectively; the oven temperature was programmed from $60-300{ }^{\circ} \mathrm{C}$ in $\mathrm{HP}-5$ column and $60-230^{\circ} \mathrm{C}$.

Compound identification was based on a comparison of the retention indices (determined relatively to the retention times of a series of $n$ alkanes) and mass spectra with those of authentic samples and/or with literature data (Adams, 2007).

\section{Acaricidal tests}

The essential oils and fractions were serially diluted in ethanol $(95 \%)$ in order to obtain the concentrations of $25.0,12.5,6.25,5.0,2.5,1.25$ and $0.625 \mu \mathrm{L} / \mathrm{mL}$. The Mozo strain used as susceptible reference strain was provided by the IPVDF (Instituto de Pesquisas Veterinárias Desidério Finamor). Engorged females $R$. (B.) microplus were collected from the infested animals, washed with water and dried in paper towel. The average weight of engorging ticks was $0.3 \mathrm{~g}$. These females were incubated at $27-28{ }^{\circ} \mathrm{C}$ and $70-80 \%$ relative humidity for two weeks until the egg laying. These eggs provided the larvae used for the larval immersion test - LIT (Ribeiro et al. 2007).

The LIT was conducted by placing approximately 100 embryonated eggs $(0.005 \mathrm{~g})$ into pockets $(1.0$ $\mathrm{cm} \times 1.5 \mathrm{~cm}$ ) made with TNT fabric. The pockets were incubated at $27-28{ }^{\circ} \mathrm{C}$ and $70-80 \%$ relative humidity for 14 days, until the eggs started to hatch. After another 14 days, the pockets containing the larvae ready for testing were immersed for 5 minutes in $10-20 \mathrm{~mL}$ of the test solutions. Ethanol (95\%) was used as control. After $1 \mathrm{~h}$ to allow the solvent to evaporate, the pockets were incubated at $27-28{ }^{\circ} \mathrm{C}$ and $70-80 \%$ relative humidity for $48 \mathrm{~h}$ and then larvae (alive and dead) were counted to assess the percent mortality. Each treatment contained three replicates. 


\section{RESULTS AND DISCUSSION}

The citronella and pepper tree essential oils have been widely used as insect repellent. Several studies have been done and the efficacy of the oils against mosquitos and ticks has been demonstrated. Nevertheless, no study has been carried out with the essential oil fractionated by vacuum distillation. In order to prepare the fractions, the essential oils obtained from the aerial parts of $C$. winterianus and from the fruits and aerial parts of $S$. molle by steam distillation were submitted to vacuum distillation at constant pressure varying the temperatures. The average yield of each fraction was calculated from the relationship between the fraction volume and essential oils volume. The results are shown in Table 1.

Table 1 - Yield of $C$. winterianus and S. molle essential oil fractions obtained by vacuum distillation.

\begin{tabular}{ccccc}
\hline \multicolumn{4}{c}{ C. winterianus } & \multicolumn{3}{c}{ S. molle } \\
\hline Fractions & Temperature Range $\left({ }^{\circ} \mathbf{C}\right)$ & Yield $(\%$ v/v) & Temperature Range $\left({ }^{\mathbf{O}} \mathbf{C}\right)$ & Yield $(\%$ v/v) \\
\hline FR1 & $25-50$ & 10.0 & $25-35$ & 12.0 \\
FR2 & $50-75$ & 16.5 & $35-50$ & 18.0 \\
FR3 & $75-100$ & 15.0 & $>50$ & 70.0 \\
FR4 & $100-125$ & 13.5 & & \\
FR5 & $>125$ & 45.0 & & \\
\hline
\end{tabular}

The percentages of each component of the $C$. winterianus and $S$. molle essential oils and fractions obtained by vacuum distillation are reported as raw percentages without standardization in the Table 2 and Table 3, respectively. Some compounds not detected in the essential oils and present in the heavy fractions could be formed by thermal degradation or they were detected in these fractions since the main components, more volatiles, were removed in the former fractions.

Laboratory tests were carried out to determine the toxicity of the citronella and pepper tree essential oil fractions on the larvae of the cattle tick $R$. (B.) microplus by the larval immersion test. In the experiments performed with the citronella essential oil and fractions, the samples presented activity in relation to the control. According to the lethal concentration values (LC) presented in Table 4, the fractions FR1 and FR2 were less active than the total essential oil. Fraction FR3 presented LC values similar to those obtained for the essential oil while fractions FR4 and FR5 proved to be the most active samples. Although the chemical composition of the fractions FR4 and FR5 were different, the activities did not differ significantly. In the present study, the essential oil of $C$. winterianus demonstrated activity against the larvae of the cattle tick in concentrations lower than those previously reported (Olivo et al. 2008).
The result could be explained by the variability in the components of the essential oil due to environmental factors or by the susceptibility of the strain.

Martins (2006) demonstrated that when tested separately, citronellal and geraniol exhibited higher acaricidal properties compared to citronellol. Nevertheless, in this work, the fractions containing lower amount of citronellal were the most active. The high activity could be enhanced by the presence of higher amount of geraniol. The activity of the fraction FR5 could be attributed to the geraniol and to the presence of sesquiterpenes and diterpenes, which, due to the higher molecular weight, could remain longer in contact with the parasite.

The other essential oil investigated in this work, the pepper tree essential oil, has been previously studied showing antimicrobial and repellent activity (Ferrero et al. 2006, Ferrero et al. 2007; Hayouni et al. 2008, Huerta et al. 2010). In this work, the toxicity of the $S$. molle essential oil and fractions obtained by the vacuum distillation on larvae of the cattle tick $R$. (B.) microplus was determined, as shown in Table 5. In relation to fractionation of $S$. molle essential oil, it could be seen that the less volatile fraction, FR3, presented acaricidal activity, while for the other fractions and the essential oil this activity against the cattle tick was not observed. 
Table 2 - GC-MS of $C$. winterianus essential oil and fractions obtained by vacuum distillation.

\begin{tabular}{|c|c|c|c|c|c|c|c|}
\hline \multirow{2}{*}{ Compound } & \multirow{2}{*}{$\mathbf{R} \mathbf{I}^{\mathbf{b}}$} & \multicolumn{6}{|c|}{$\operatorname{Area}\left(\%^{a}\right)$} \\
\hline & & $\mathbf{E O}^{\mathbf{c}}$ & FR1 & FR2 & FR3 & FR4 & FR5 \\
\hline tricyclene & 921 & $\operatorname{tr}^{\mathrm{d}}$ & $\operatorname{tr}$ & - & - & - & - \\
\hline$\alpha$-thujene & 924 & $\operatorname{tr}$ & - & - & - & - & - \\
\hline$\alpha$-pinene & 932 & $\operatorname{tr}$ & 0.140 & - & - & - & - \\
\hline camphene & 946 & $\operatorname{tr}$ & $\operatorname{tr}$ & - & - & - & - \\
\hline sabinene & 969 & $\operatorname{tr}$ & 0.158 & - & - & - & - \\
\hline$\beta$-pinene & 974 & $\operatorname{tr}$ & 0.112 & - & - & - & - \\
\hline myrcene & 988 & $\operatorname{tr}$ & 0.266 & $\operatorname{tr}$ & 0.626 & 1.147 & - \\
\hline$\alpha$-felandrene & 1002 & $\operatorname{tr}$ & 0.171 & - & - & - & - \\
\hline$\alpha$-terpinene & 1014 & $\operatorname{tr}$ & - & - & - & - & - \\
\hline o-cymene & 1022 & $\operatorname{tr}$ & - & - & - & - & - \\
\hline limonene & 1024 & 4.120 & 26.193 & 4.978 & 0.321 & 0.155 & - \\
\hline 1,8-cineole & 1026 & $\operatorname{tr}$ & - & 0.366 & 0.195 & - & - \\
\hline Z- $\beta$-ocymene & 1032 & $\operatorname{tr}$ & - & - & 0.285 & 0.487 & - \\
\hline E- $\beta$-ocymene & 1044 & $\operatorname{tr}$ & - & - & 0.468 & 0.873 & - \\
\hline bergamal & 1051 & 0.118 & 0.427 & & - & - & - \\
\hline$\gamma$-terpinene & 1054 & $\operatorname{tr}$ & $\operatorname{tr}$ & - & - & - & - \\
\hline p-mentha-3,8-diene & 1068 & $\operatorname{tr}$ & - & - & 0.116 & 0.120 & - \\
\hline terpinolene & 1086 & $\operatorname{tr}$ & 0.330 & $\operatorname{tr}$ & - & $\operatorname{tr}$ & - \\
\hline linallol & 1095 & 0.777 & 1.511 & 1.871 & 1.685 & 1.000 & - \\
\hline$c i s$-rose oxide & 1106 & $\operatorname{tr}$ & 0.110 & 0.121 & 0.131 & $\operatorname{tr}$ & - \\
\hline trans-rose oxide & 1122 & $\operatorname{tr}$ & - & - & $\operatorname{tr}$ & - & - \\
\hline isopulegol & 1145 & 1.371 & 2.764 & 5.241 & 6.959 & 3.198 & 0.263 \\
\hline citronellal & 1148 & 37.987 & 41.292 & 53.851 & 38.711 & 16.76 & 1.811 \\
\hline iso-isopulegol & 1155 & $\operatorname{tr}$ & 0.424 & 0.366 & - & 0.404 & - \\
\hline isomenthone & 1162 & $\operatorname{tr}$ & 0.180 & 1.414 & 2.023 & 1.030 & - \\
\hline terpinen-4-ol & 1174 & $\operatorname{tr}$ & 0.132 & - & - & - & - \\
\hline$\alpha$-terpineol & 1186 & $\operatorname{tr}$ & 0.133 & $\operatorname{tr}$ & 0.140 & 0.156 & - \\
\hline$n$-decanal & 1201 & 0.116 & 4.748 & 0.119 & 0.107 & $\operatorname{tr}$ & - \\
\hline citronellol & 1223 & 12.030 & 0.195 & 6.994 & 10.052 & 15.829 & 12.445 \\
\hline neral & 1235 & 0.412 & 6.532 & 0.331 & 0.406 & 0.427 & 0.139 \\
\hline geraniol & 1249 & 16.606 & 0.264 & 9.108 & 11.848 & 17.389 & 17.018 \\
\hline geranial & 1264 & 0.501 & - & 0.416 & 0.375 & 0.288 & - \\
\hline citronellyl formate & 1271 & $\operatorname{tr}$ & $\operatorname{tr}$ & $\operatorname{tr}$ & 0.186 & 0.282 & - \\
\hline bornyl acetate & 1287 & $\operatorname{tr}$ & - & - & - & - & - \\
\hline geranyl formate & 1298 & $\operatorname{tr}$ & $\operatorname{tr}$ & $\operatorname{tr}$ & 0.191 & 0.296 & - \\
\hline citronelic acid & 1312 & 0.196 & - & - & - & - & - \\
\hline 8-hydroxy-neo-menthol & 1328 & 0.232 & 2.560 & - & - & - & - \\
\hline$\alpha$-cubebene & 1345 & $\operatorname{tr}$ & - & - & 0.105 & $\operatorname{tr}$ & - \\
\hline citronellyl acetate & 1350 & 2.028 & 1.293 & 2.069 & & 5.768 & 4.183 \\
\hline eugenol & 1356 & 1.215 & 1.131 & 0.225 & $4.435^{*}$ & 0.674 & 0.954 \\
\hline$\alpha$-copaene & 1374 & $\operatorname{tr}$ & - & - & $\operatorname{tr}$ & 0.111 & - \\
\hline geranyl acetate & 1379 & 1.325 & 1.136 & 1.867 & 3.612 & 5.435 & 5.253 \\
\hline$\beta$-elemene & 1389 & 1.850 & 1.586 & 2.537 & 4.574 & 6.201 & 4.870 \\
\hline E- cariophyllene & 1417 & 0.118 & - & $\operatorname{tr}$ & 0.140 & 0.203 & 0.195 \\
\hline$\beta$-copaene & 1430 & $\operatorname{tr}$ & - & - & - & $\operatorname{tr}$ & 0.320 \\
\hline$\alpha$-humulene & 1452 & 0.136 & - & $\operatorname{tr}$ & 0.141 & 0.220 & - \\
\hline trans-cadina-1(16),4-diene & 1475 & $\operatorname{tr}$ & $\operatorname{tr}$ & - & - & 0.046 & - \\
\hline$\gamma$-muurolene & 1478 & 0.260 & 0.179 & 0.130 & 0.254 & 0.436 & 0.706 \\
\hline germacrene D & 1484 & 2.322 & - & & - & - & - \\
\hline$\beta$-selinene & 1489 & 0.146 & - & - & - & 0.120 & 0.296 \\
\hline$\alpha$-selinene & 1498 & 0.278 & 0.181 & - & - & 0.121 & 0.229 \\
\hline$\alpha$-muurolene & 1500 & 0.674 & - & 0.289 & 0.555 & 0.908 & 1.686 \\
\hline
\end{tabular}


(cont.Table 2)

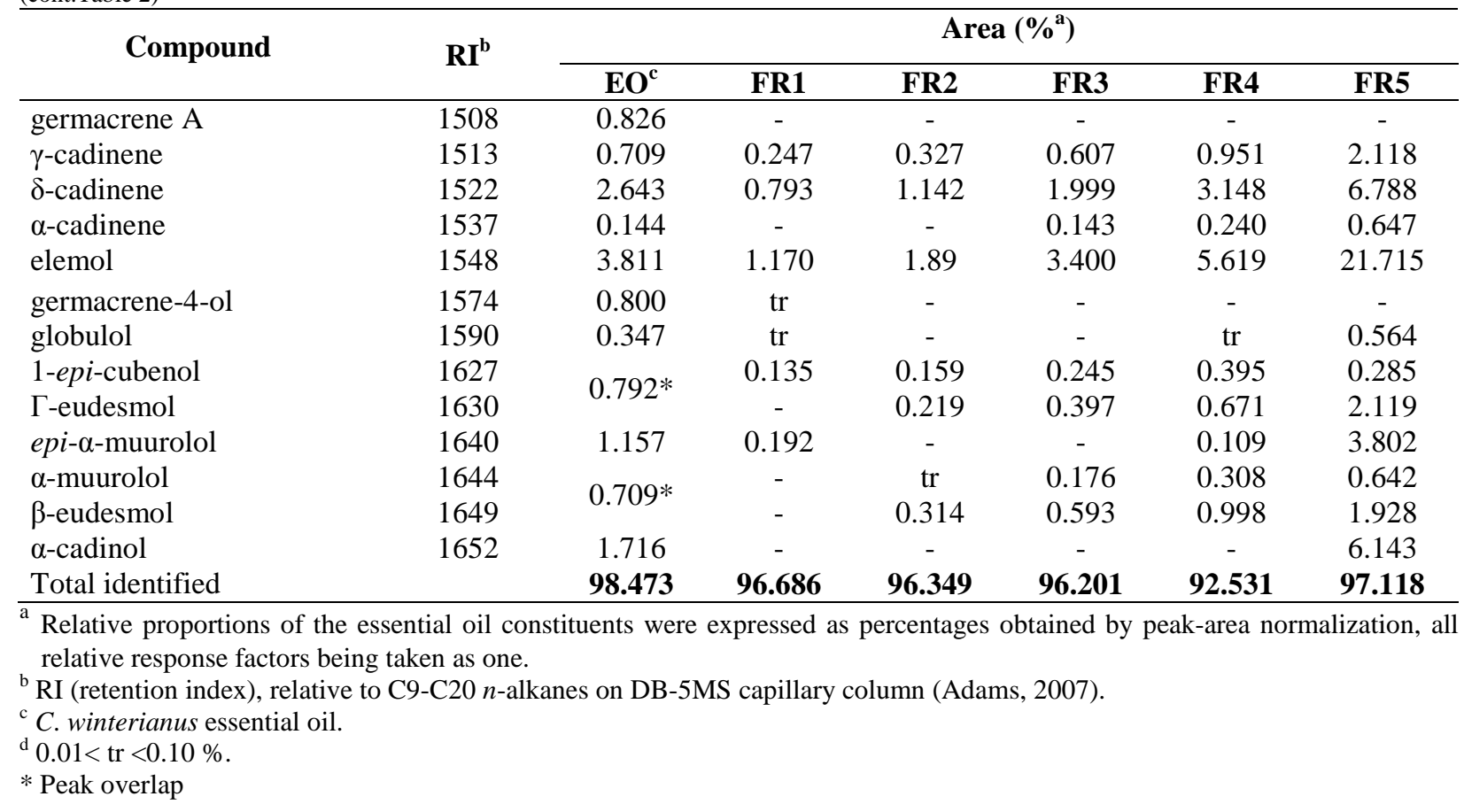

Table 3 - GC-MS of $S$. molle essential oil and fractions obtained by vacuum distillation.

\begin{tabular}{|c|c|c|c|c|c|}
\hline \multirow{2}{*}{ Compound } & \multirow{2}{*}{$\mathbf{R I}^{\mathbf{b}}$} & \multicolumn{4}{|c|}{$\operatorname{Area}\left(\%^{a}\right)$} \\
\hline & & $\mathbf{E O}^{\mathbf{c}}$ & FR1 & FR2 & FR3 \\
\hline tricyclene & 921 & 0.045 & 0.106 & $\operatorname{tr}$ & - \\
\hline$\alpha$-thujene & 924 & 1.782 & 3.861 & 3.312 & 0.431 \\
\hline$\alpha$-pinene & 932 & 8.345 & 18.479 & 17.114 & 3.243 \\
\hline camphene & 946 & 0.32 & 0.577 & 0.569 & 0.124 \\
\hline sabinene & 969 & 34.301 & 53.578 & 57.149 & 28.501 \\
\hline$\beta$-pinene & 974 & 2.979 & 6.94 & 7.828 & 5.225 \\
\hline myrcene & 988 & 1.985 & 1.773 & 1.694 & 0.964 \\
\hline$\alpha$-felandrene & 1002 & 0.178 & 0.126 & 0.549 & 0.334 \\
\hline$\alpha$-terpinene & 1014 & 1.892 & 1.107 & - & - \\
\hline o-cymene /p-cymene & $1022 / 1020$ & 4.517 & 3.177 & 5.025 & 8.964 \\
\hline limonene & 1024 & 5.987 & 4.354 & 4.610 & 6.493 \\
\hline E- $\beta$-ocymene & 1044 & 0.143 & - & - & $\operatorname{tr}$ \\
\hline$\gamma$-terpinene & 1054 & 3.598 & 1.385 & 0.956 & 1.524 \\
\hline cis-sabinene hydrate & 1065 & $\operatorname{tr}$ & - & - & 0.134 \\
\hline terpinolene & 1086 & 1.049 & 0.297 & 0.221 & 0.615 \\
\hline trans-sabinene hydrate & 1098 & $\operatorname{tr}$ & - & - & 0.135 \\
\hline cis-p-menth-2-en-1-ol & 1118 & 0.281 & - & - & 0.364 \\
\hline trans-sabinol & 1137 & $\operatorname{tr}$ & - & - & 0.184 \\
\hline terpinen-4-ol & 1174 & 8.214 & 1.157 & 0.683 & 11.091 \\
\hline p-cimen-8-ol & 1179 & 0.274 & - & - & 0.702 \\
\hline$\alpha$-terpineol & 1186 & 0.428 & - & - & 0.570 \\
\hline trans-piperitol & 1207 & 0.175 & - & - & 0.248 \\
\hline trans-ascaridol glycol & 1266 & $\operatorname{tr}$ & - & - & 0.362 \\
\hline p-cymen-7-ol & 1289 & $\operatorname{tr}$ & - & - & 0.334 \\
\hline carvacrol & 1298 & 0.333 & - & - & 0.384 \\
\hline$\alpha$-copaene & 1374 & 0.295 & - & - & 0.394 \\
\hline$\beta$-elemene & 1389 & 0.198 & - & - & 0.585 \\
\hline$\alpha$-gurjunene & 1409 & 0.182 & - & - & 0.186 \\
\hline
\end{tabular}




\begin{tabular}{|c|c|c|c|c|c|}
\hline \multirow{2}{*}{ Compound } & \multirow{2}{*}{$\mathbf{R I}^{\mathbf{b}}$} & \multicolumn{4}{|c|}{$\operatorname{Area}\left(\%^{a}\right)$} \\
\hline & & $\mathbf{E O}^{\mathbf{c}}$ & FR1 & FR2 & FR3 \\
\hline E- cariophyllene & 1417 & 2.276 & 0.171 & 0.121 & 2.589 \\
\hline aromandrene & 1439 & $\operatorname{tr}$ & - & - & $\operatorname{tr}$ \\
\hline$\alpha$-humulene & 1452 & 0.328 & - & - & 0.324 \\
\hline 9-epi-E-cariofilene & 1464 & 1.812 & 0.111 & - & 2.427 \\
\hline$\gamma$-muurolene & 1478 & 0.14 & - & - & $\operatorname{tr}$ \\
\hline germacrene D & 1484 & 1.348 & - & - & 0.623 \\
\hline valencene & 1496 & 0.161 & - & - & - \\
\hline bicyclogermacrene & 1500 & 1.215 & - & - & 0.426 \\
\hline$\alpha$-muurolene & 1500 & 0.513 & - & - & 0.686 \\
\hline$\gamma$-cadinene & 1513 & 2.227 & 0.107 & - & 2.843 \\
\hline$\delta$-cadinene & 1522 & 1.764 & - & - & 2.169 \\
\hline$\alpha$-cadinene & 1537 & 0.153 & - & - & - \\
\hline nerolidol & 1561 & 0.133 & - & - & 0.111 \\
\hline spathulenol & 1577 & 2.222 & - & - & 1.787 \\
\hline gleenol & 1586 & 0.344 & - & - & - \\
\hline ledol & 1602 & 0.114 & - & - & - \\
\hline 1.10-di-epi-cubenol & 1618 & 0.595 & - & - & 0.580 \\
\hline 1-epi-cubenol & 1627 & $\operatorname{tr}$ & - & - & - \\
\hline epi- $\alpha$-cadinol & 1638 & 4.276 & - & - & 6.631 \\
\hline TOTAL & & $97.132 \%$ & $99.662 \%$ & $99.831 \%$ & $93.286 \%$ \\
\hline
\end{tabular}

${ }^{a}$ Relative proportions of the essential oil constituents were expressed as percentages obtained by peak-area normalization, all relative response factors being taken as one.

${ }^{\mathrm{b}} \mathrm{RI}$ (retention index), relative to C9-C20 n-alkanes on DB-5MS capillary column (Adams. 2007).

${ }^{\mathrm{c}} S$. molle essential oil.

${ }^{\mathrm{d}} 0.01<\operatorname{tr}<0.10 \%$.

Table 4 - Lethal concentration values $(\mu \mathrm{L} / \mathrm{mL})$ of the essential oil of $C$. winterianus and fractions obtained by vacuum distillation on the larvae of $R$. (B.) microplus.

\begin{tabular}{ccccccc}
\hline $\mathrm{LC}(\mu \mathrm{L} / \mathrm{mL})$ & FR1 & FR2 & FR3 & FR4 & FR5 & C. winterianus EO \\
\hline $\mathrm{LC}_{1}$ & 2.42 & 1.75 & 0.63 & $\mathrm{ND}$ & $\mathrm{ND}$ & 0.70 \\
$\mathrm{LC}_{50}$ & 4.37 & 4.24 & 3.49 & 1.19 & 1.34 & 3.30 \\
$\mathrm{LC}_{99.9}$ & 6.86 & 6.85 & 6.41 & 4.38 & 4.19 & 5.95 \\
\hline
\end{tabular}

ND: not verified; LC values were determined by linear regression; EO essential oil.

Table 5 - Lethal concentration values $(\mu \mathrm{L} / \mathrm{mL})$ of the essential oil of $S$. molle and fractions obtained by vacuum distillation on the larvae of $R$. (B.) microplus

\begin{tabular}{ccccc}
\hline $\mathrm{LC}(\mu \mathrm{L} / \mathrm{mL})$ & FR1 & FR2 & FR3 & S. molle EO \\
\hline $\mathrm{LC}_{1}$ & $\mathrm{ND}$ & $\mathrm{ND}$ & 5.13 & ND \\
$\mathrm{LC}_{50}$ & $\mathrm{ND}$ & $\mathrm{ND}$ & 8.8 & ND \\
$\mathrm{LC}_{99.9}$ & $\mathrm{ND}$ & $\mathrm{ND}$ & 12.5 & ND \\
\hline
\end{tabular}

ND: not verified; LC values were determined by linear regression, OE essential oil.

Results from this study showed that the less volatile fractions were more active against the tick, which indicated that the contact time of the extract with the larvae was a factor that could influence the toxic effects. It was also observed that the chemical composition of the fractions varied significantly, which indicated the influence of chemical composition on acaricidal activity. These observations were only possible due to processing by vacuum distillation of essential oils, and thus, obtaining new fraction for the testing of volatile compounds against the cattle ticks. 


\section{CONCLUSIONS}

From the results, it could be concluded that the less volatile essential oil fractions obtained by vacuum distillation were more active against the cattle tick larvae. Especially for the $S$. molle essential oil, it was observed that a change in the composition caused a significant variation in acaricidal activity. The citronella essential oil fractions presented different behavior against the cattle tick, mainly the fractions FR4 and FR5, when compared with the total essential oil. Results showed that the use of vacuum distillation process could be an alternative in the development of new natural products to be used in the tick control, since the changes in the composition of the essential oils promoted a change in their toxicity against the larvae of $R$. (B.) microplus.

\section{ACKNOWLEDGMENTS}

The authors would like to thank to Programa CYTED, CAPES and CNPq for financial support.

\section{REFERENCES}

Adams RP. Identification of Essential Oil Components by Gas Chromatography/Mass Spectrometry. Allured, Illinois, USA; 2007.

Apel MA, Sardá Ribeiro VL, Bordignon SAL, Henriques AT, von Poser G. Chemical composition and toxicity of the essential oils from Cunila species (Lamiaceae) on the cattle tick Rhipicephalus (Boophilus) microplus. Parasitol Res. 2009; 105: 863-868.

Babu KGD, Kaul VK. Variations in quantitative and qualitative characteristics of wild marigold (Tagetes minuta L.) oils distilled under vacuum and at NTP. Ind Crops Prod. 2007; 26: 241-251.

Borges LMF, Ferri PH, Silva WJ, Silva WC, Silva JG. In vitro efficacy of extracts of Melia azedarach against the tick Boophilus microplus. Med Vet Entomol. 2003; 17: 228-231.

Cassel E, Vargas RMF. Experiments and modeling of the Cymbopogon winterianus essential oil extraction by steam distillation. J Mex Chem Soc. 2006; 50: 126-129.

Cassel E, Vargas RMF, Martinez N, Lorenzo D, Dellacassa E. Steam distillation modeling for essential oil extraction process. Ind Crops Prod. 2009; 29: 171-176.

Castro-Janer E, Rifran L, Piaggio J, Gil A, Miller RJ, Schumaker TTS. In vitro tests to establish LC50 and discriminating concentrations for fipronil against Rhipicephalus (Boophilus) microplus (Acari: Ixodidae) and their standardization. Vet Parasitol. 2009; 162: 120-128.

Chagas ACS. Controle de parasitas utilizando extratos vegetais. Rev Bras Parasiltol Vet. 2004; 13: 156-160.

Chagas ACS, Prates HT, Leite RC, Furlong J. Ação larvicida de derivados arilsulfonílicos da (+)-cânfora e da (+)-isopinocanfona sobre o carrapato Boophilus microplus. Arq Bras Med Vet Zootec. 2002; 54: 462467.

Chungsamarnyart N, Jiwajinda S. Acaricidal activity of volatile oil from lemon and citronella grasses on tropical cattle ticks. Kasetsart J. 1992; 26: 46-51.

Cordovés CO. Carrapato: controle ou erradicação. Porto Alegre: Guaíba Agropecuária; 1997.

Dietrich G, Dolan MC, Peralta-Cruz J, Schmidt J, Piesman J, Eisen RJ, Karchesy JJ. Repellent activity of fractioned compounds from Chamaecyparis nootkatensis essential oil against nymphal Ixodes scapularis (Acari: Ixodidae). J Med Entomol. 2006; 43: 957-961.

Ducornez S, Barré N, Miller RJ, de Garine-Wichatitsky M. Diagnosis of amitraz resistance in Boophilus microplus in New Caledonia with the modified Larval Packet Test. Vet Parasitol. 2005; 130: 285292.

Facey PC, Porter RB, Reese PB, Williams LA. Biological activity and chemical composition of the essential oil from Jamaican Hyptis verticillata Jacq. $J$ Agric Food Chem. 2005; 53: 4774-4777.

Fernandes FF, Bessa PAD, Paula E, Freitas S. Evaluation of Activity of the Crude Ethanolic Extract of Magonia pubescens St. Hil (Sapindaceae) Against Larvae of the Cattle Tick Rhipicephalus (Boophilus) microplus (Canestrini, 1887) (Acari: Ixodidae). Braz Arch Biol Technol. 2008; 51: 1147-1152.

Ferrero AA, Sánchez Chopa C, Werdin González JO, Alzogaray RA. Repellence and toxicity of Schinus molle extracts on Blattella germanica. Fitoterapia. 2007; 78: 311-314.

Ferrero AA, Werdin González JO, Sánchez Chopa C Biological activity of Schinus molle on Triatoma infestans. Fitoterapia. 2006; 77: 381-383.

Freitas-Ribeiro GM, Furlong J, Vasconcelos VO, Dolinski C, Loures-Ribeiro A. Analysis of Biological Parameters of Boophilus microplus Canestrini, 1887 Exposed to Entomopathogenic Nematodes Steinernema carpocapsae Santa Rosa and All Strains (Steinernema: Rhabditida). Braz Arch Biol Technol. 2005; 48: 911-919.

Hayouni EA, Chraief I, Abedrabba M, Bouix M, Leveau JY, Mohammed H, Hamdi M. Tunisian Salvia officinalis L. and Schinus molle L. essential oils: Their chemical compositions and their preservative effects against Salmonella inoculated in minced beef meat. Int J Food Microbiol. 2008; 125: 242-251. 
Huerta A, Chiffelle I, Puga K, Azúa F, Ara ya JE. Toxicity and repellence of aqueous and ethanolic extracts from Schinus molle on elm leaf beetle Xanthogaleruca luteola. Crop Prot. 2010; 29: 11181123.

García-García JC, Gonzalez IL, González DM, Valdés M, Méndez L, Lamberte J, D'Agostino B, Citroni D, Fragos, H, Ortiz M, Rodríguez M, De La Fuente J. Sequence variations in the Boophilus microplus Bm86 locus and implications for immunoprotection in cattle vaccinated with this antigen. Exp Appl Acarol. 1999; 23: 883-895.

Ketoh GK, Koumaglo HK, Glitho IA, Huignard J. Comparative effects of Cymbopogon schoenanthus essential oil and piperitone on Callosobruchus maculatus development. Fitoterapia. 2006; 77: 506510.

Kim S, Yi J, Tak J, Ahn YJ. Acaricidal activity of plant essential oils against Dermanyssus gallinae (Acari: Dermanyssidae). Vet Parasitol. 2004; 120: 297-304.

Olivo CJ, Carvalho NM, Silva JHS, Vogel FF, Massariol P, Meinerz G, Agnolin C, Morel AF, Viau LV. Citronella oil on the control of cattle ticks. Ciênc Rural. 2008; 38: 406-410.

Martins RM. In vitro study of the acaricidal activity of the essential oil from the Citronella of Java (Cymbopogon winterianus Jowitt) to the tick Boophilus microplus. Rev Bras Pl Med. 2006; 8: 7178.

Panella NA, Dolan MC, Karchesy JJ, Xiong Y, PeraltaCruz J, Khasawneh M, Montenieri JA, Maupin GO. Use of novel compounds for pest control: insecticidal and acaricidal activity of essential oil components from heartwood of Alaska yellow cedar. J Med Entomol. 2005; 42: 352-358.
Ribeiro VLS, Toigo E, Bordignon SAL, Gonçalves K, von Poser GL. Acaricidal properties of extracts from the aerial parts of Hypericum polyanthemum on the cattle tick Boophilus microplus. Vet Parasitol. 2007; 147: 199-203.

Ribeiro VLS, Avancini C, Gonçalves K, Toigo E, Von Poser G. Acaricidal activity of Calea serrata (Asteraceae) on Boophilus microplus and Rhipicephalus sanguineus. Vet Parasitol. 2008; 151: 351-354.

Samarasekera R, Kalhari KS, Weerasinghe IS. Insecticidal Activity of Essential Oils of Ceylon Cinnamomum and Cymbopogon species against Musca domestica. J Essent Oil Res. 2006; 18: 352354.

Tanu PA, Adholeya A. Effect of different organic manures/composts on the herbage and essential oil yield of Cymbopogon winterianus and their influence on the native AM population in a marginal alfisol. Biores Technol. 2004 ; 92: 311-319.

Tunon H, Thorsell W, Mikiver A, Malander I. Arthropod repellency, especially tick (Ixodes ricinus), exerted by extract from Artemisia abrotanum and essential oil from flowers of Dianthus caryophyllum. Fitoterapia. 2006; 77: 257-261.
Received: April 07, 2011; Revised: October 11, 2011; Accepted: May 07, 2012. 
PAGINA

EM

BRANCO 